\title{
IMPLEMENTATION OF FLOOD DISASTER MITIGATION STRATEGY IN NAGARI TARAM, LIMAPULU KOTA REGENCY
}

\author{
"Rahmadani Yusran ${ }^{12}$, Zikri Alhadi ${ }^{1}$, Zahari Basri ${ }^{1}$, Rika Sabri ${ }^{2}$ \\ ${ }^{*}$ Department of Administration, Universitas Negeri Padang - Indonesia \\ ${ }^{2}$ Doctoral Program of Environmental Science, Universitas Negeri Padang - Indonesia \\ ${ }^{3}$ Study Program of Community and Psychiatric, Department of Nursing, Faculty of Nursing, Universitas \\ Andalas - Indonesia \\ Email: yusranrdy@fis.unp.ac.id
}

*Corresponding Author, Received: March 8, 2021. Revised: March 21, 2021. Accepted: May 20, 2021

\begin{abstract}
This study aims to analyze the implementation of flood disaster mitigation strategies in Nagari Taram, Limapuluh Kota Regency. This study uses a qualitative method with a descriptive approach. They were collecting data using interviews, observation, and documentation study. The research informants were several heads of fields, section heads in the Regional Disaster Management Agency of Fifty Cities Distr2ict. The results showed that the implementation of disaster mitigation by the local government had been carried out in the form of the normalization of Batang Sinamar, brojong development along the Batang Sinamar watershed. However, the mitigation that has been implemented has not succeeded in reducing the risk and impact of flooding on the community in Nagari Taram. This study argues that local governments need to pay attention to regional characteristics in implementing flood disaster mitigation before carrying out river normalization because the area's characteristics affect the carrying capacity and carrying capacity of the river.
\end{abstract}

Keywords: Implementation, Flood, Disaster, Mitigation, Limapuluh Kota

\section{INTRODUCTION}

Implementation of disaster mitigation strategies is an essential part of disaster risk management. Through a disaster mitigation implementation strategy, various activities can be carried out to ensure that each organization and related institutions can respond effectively to and reduce disaster risk. In addition, implementing a disaster risk management strategy can improve understanding of disaster risk in various dimensions of vulnerability, capacity, hazard characteristics, and the environment. Furthermore, it can be used in conducting risk assessments, prevention, mitigation, preparedness, and response.

Conceptually disaster management can be interpreted as all efforts or activities carried out in the framework of prevention, mitigation, preparedness, emergency response, and recovery efforts related to disasters carried out in the stages before, during, and after a disaster. According to Law No. 24/2007 concerning Disaster Management, a disaster is an event or series of events that threatens and disrupts the life and livelihood of the community as a result of both natural and non-natural factors and human factors-resulting in casualties, environmental damage, property loss, and psychological impacts. To what extent has the disaster risk management as stipulated in this law been implemented? Have you been able to anticipate the various risks posed by the disaster?

UU No. 24/2007 also stipulates that the potential causes of disasters in the territory of the unitary state of Indonesia can be divided into 3 (three) types of disasters, namely natural disasters, non-natural disasters, and social disasters. Natural disasters include earthquakes due to nature, volcanic winds, floods, landslides, drought, forest/land fires due to natural factors, plant pests, disease outbreaks, disease outbreaks, extraordinary events, and space events/objects.

Indonesia is a country that is often hit by various disasters. Based on data compiled in Indonesia's Disaster Information Data (DIBI) $\mathrm{BNPB}$, it can be seen that of the more than 1,800 disaster events in the 2005-2015 period, more than $78 \%(11,648)$ were hydrometeorological disasters, and only around $22 \%(3,810)$ were a geological disaster. Hydrometeorological group disasters include floods, extreme waves, forest and land fires, drought, and extreme weather. Meanwhile, geological disasters that often occur are earthquakes, tsunamis, volcanic eruptions, and 
landslides. The tendency for the number of disaster occurrences for these two types of groups is relatively increasing.

A flood disaster is an event or series of events that threatens and disrupts people's lives and livelihoods caused by overflowing river water caused by natural factors due to damage to the buffer zone in the upper das (river basin) area. As a result, human casualties, environmental damage, property losses, and psychological damages have occurred. Meanwhile, flood disaster mitigation is a series of efforts to reduce the risk of flood disasters, both through physical development and awareness and increasing the ability to face the threat of floods [1].

According to $[2,3]$, the problem of flooding is caused by two things; namely, the first is because of human activity and because of natural conditions. The consequences of human activity are the emergence of new settlements in riverbank areas, changes in land use in both upstream and downstream areas, maintenance of buildings that are very difficult to control flooding, some throwing garbage in drainage channels, destroying forests in upstream areas, and closing or compaction of surfaces, land by building. Meanwhile, natural conditions can be in high rainfall, the flow of tributaries being held back by the main river flow, or backflow and damming of the river estuary due to tidal water.

In the context of implementing a disaster risk management strategy in Nagari Taram Regency 50 Cities, disaster mitigation is a series of efforts to reduce the risk of flood disasters, both through physical development and awareness and increasing the ability to face the threat of floods [1]. So far, the flood disaster mitigation has been carried out by the Regency Government of Fifty Cities through BPBD of Fifty Cities Regency. This flood disaster mitigation also involves cooperation and coordination with the Public Works and Spatial Planning Office and the Nagari Taram Government to build flood-prevention turrets and strengthen riverbanks to prevent erosion.

The Nagari Taram area is an area that experiences flooding almost every year from the overflow of the Batang Sinamar river. Floods that occur in Taram Nagari usually occur in November and December or during the peak of the rainy season. Based on the Secretary of the Wali Nagari Taram, Gusnedy stated that the flood in Nagari Taram is an annual flood that almost occurs every year from 2011-2019. Flood height usually varies from the knee-high of an adult to as high as 2 meters. Floods in Taram have an impact on the damage to residential areas and community rice fields. Floods in Taram are caused by high rainfall, so that the Batang Sinamar river is unable to accommodate water discharge.
The government must be responsible for disaster management as stipulated in Law No. 24/2007 concerning Disaster Management. This law stipulates that those responsible for implementing disaster management are the central government and regional governments through non-departmental government agencies, namely the National Disaster Management Agency (BNPB) at the central level and BPBD at the regional level. With the existence of $\mathrm{BPBD}$, it is hoped that natural disasters occur in areas that are responsive to the possibility of natural disasters [4].

However, the strategy of the Fifty Cities Regency Government through BPBD has not succeeded in implementing disaster mitigation. Disaster mitigation has not been implemented as it should be because many activities of the Fifty Cities Regency Government through BPBD are focused on the emergency response phase. Not many infrastructure facilities have been built in the Batang Sinamar watershed to prevent the impact of flooding. Not only that but efforts to build community awareness along the Batang Sinamar watershed towards environmental preservation have also not been implemented. As a result, floods often occur during the rainy season in residential areas and people's rice fields. This phenomenon has an impact on the loss of people's income. Disaster mitigation is carried out to prevent and reduce the risk of flood disasters, both through physical development and awareness and increased capacity to face the threat of floods [1].

\section{RESULTS AND DISCUSSION}

In general, flood risk mitigation has been developed and implemented at the local or regional level [5]. The goal is to be a more efficient and sustainable solution to flood risk than flood defense. The steps taken are with solid support from stakeholders [6], encourage the responsibility of local authorities [7], and emphasize the local economic benefits of mitigation measures to communities [8]. Implemented effectively if integration into sustainable development policies, plans, and programs at all levels, with particular emphasis on prevention, mitigation, and mitigation of disaster vulnerability, according to [4].

Flood disaster mitigation carried out in Nagari Taram aims to prevent flooding. Flood disaster mitigation carried out in Nagari Taram aims to prevent flooding. Thus, the risk of falling victims can be reduced. Furthermore, flood mitigation is carried out to prevent damage to natural resources, and of course, the essential thing is to minimize the loss of economic income for the community along the Batang Sinamar Nagari Taram watershed. This is in accordance with the 
provisions of Law No. 24/2007 that mitigation is a series of ways to reduce disaster risk or the impact of disasters that occur through physical development and awareness and capacity building to deal with disaster threats.

The length of the Batang Sinamar flow is 74.76 $\mathrm{km}$. While the surface width is $44 \mathrm{~m}$, and the bottom is $36 \mathrm{~m}$ with a river depth of $8 \mathrm{~m}$ [9]. Batang Sinamar is a river where seven other rivers can flood every year due to floods sent from the river mouths that converge to Batang Sinamar. This condition was reinforced by the statement of the Head of Emergency and Logistics Division of BPBD Regency 50 Rahmadinol City, S.Pd "... floods in Nagari Taram, Harau Regency, almost every year occur around October to December or during the rainy season, floods occur because of shipments from upstream areas".

Based on the findings in the field, the Regency Government of Fifty Cities, through the Regional Disaster Management Agency, in coordination with the Public Works and Spatial Planning Office of Fifty Cities Regency, has made flood mitigation efforts in Nagari Taram. Among them are river normalization and widening. Then, build gabions approximately $1 \mathrm{~km}$ at several points on the Batang Sinamar river. Moreover, conduct flood mitigation training for the Taram community. Gabion is a construction/building composed of rocks that are tied or knitted regularly with wire. The installation of gabions is usually installed on the edge of a cliff and follows the current of the river [10]. The construction of brojong has been carried out since 2019 with a height of $1.5 \mathrm{M}$. The goal is to restrain the speed of water discharge from protecting the cliffs from outside the water flow.

In actual fact, it appears that the flood mitigation implementation strategy carried out by the Regency government and related parties has succeeded in reducing the level of vulnerability to the community in the Batang Sinamar watershed in Nagari Taram. This result was realized from the river normalization through the construction of brojong, which spent a budget of 7 billion. This success was also supported by the willingness of the local community to provide land and rice fields for river normalization.

However, based on findings in the field, Batang Sinamar normalization has not significantly impacted overcoming the flood problem in Nagari Taram. Floods are still a vulnerable problem for people who live along the Batang Sinamar watershed. In fact, during the rainy season that occurred at the end of 2020, Batang Sinamar again overflowed with a more significant water discharge. Floods at the end of 2020 caused as many as 222 families to evacuate again as in 2018. This flood also caused damage to
250 hectares of rice fields and gardens, livestock sheds, and fish ponds belonging to the community. From the objectives of flood disaster mitigation described above, it can be said that flood disaster mitigation in Nagari Taram has not been running well because post-flood disaster mitigation still occurs. The characteristics of Kabupaten Limapuluh Kota, whose rainfall is very high, are closely related to floods. However, the local government and related parties have not considered the characteristics and characteristics of this area in carrying out flood disaster irrigation in Nagari Taram.

\section{CONCLUSION}

Based on the findings of researchers that the author has carried out regarding flood disaster mitigation by the Regional Disaster Management Agency, it appears that flood mitigation in Nagari Taram has been carried out by normalizing rivers, building gabions, as well as providing counseling, socialization, and flood mitigation training to the Taram community. However, it has not yet automatically prevented the damage caused by the flood disaster. To prevent the impact of the flood disaster that continues to threaten Nagari Taram, the Regency Government of Fifty Cities needs to consider the carrying capacity and capacity of Batang Sinamar before carrying out the normalization of Batang Sinamar. Because the normalization carried out in Batang Sinamar turned out to be unable to accommodate the high levels of rainfall in this area. This is what makes Nagari Taram and the surrounding areas vulnerable to flood hazards.

\section{ACKNOWLEDGEMENTS}

His writing this research can be carried out smoothly, because of the help and cooperation of various parties. Therefore, the author would like to thank Prof. Dr. Dedi Hermon, MP as the Deputy Director II of the Postgraduate - Universitas Negeri (also chairman of the course of disaster risk management, disaster mitigation, and Geography Information Systems/GIS in the Doctoral Program in Environmental Science, Universitas Negeri Padang) who have provided the opportunity and time to sharpen the academic ability my, especially in the field of disaster environmental.

\section{REFERENCES}

[1] Hermon, D. Mitigasi Bencana Hidrometeorologi Banjir, Longsor, Ekoligi, Degradasi Lahan, Putting Beliung, Kekeringan. 2012, Padang: UNP Press.

[2] Asdak, C. Hidrologi dan Pengelolaan Daerah Aliran Air Sungai: Edisi Revisi Kelima. 2010: 
Yogyakarta: Gadjah Mada University Press Yogyakarta.

[3] Syafri, S., Surya, B., Ridwan, R., Bahri, S., Rasyidi, E. S., and Sudarman, S. Water Quality Pollution Control and Watershed Management Based on Community Participation in Maros City, South Sulawesi, Indonesia. Sustainability, 2020, 12(24), 10260.

[4] Alhadi, Z., Maani, K. D., Nurhabibi, P., and Syarief, A. An analysis of problem in composing of tsunami contingency plan in Padang City. In MATEC Web of Conferences, 2018, 229, p. 03007.

[5] Dieperink, C., Hegger, D.L.T., Bakker, M.H.N. Recurrent Governance Challenges in the Implementation and Alignment of Flood Risk Management Strategies: a Review. Water Resour Manage, 2016, 30, 4467-4481.
[6] De Moel H, Van Alphen J, Aerts JCJH. Peta banjir di Eropa - metode, ketersediaan, dan penggunaan. Nat Hazards Earth Syst Sci, 2009, 9: 289-301.

[7] Thaler T, and Priest S (2014) Partnership funding in flood risk management: new localism debate and policy in England. Area.

[8] Holub M, Fuchs S. Mitigating mountain hazards in Austria - legislation, risk transfer, and awareness building. Natural hazards and earth system. Science, 2009. 9(2):523-537.

[9] Pemerintah Kabupaten Limapuluh Kota Provinsi Sumatera Barat. Buku Data Status Lingkungan Hidup Daerah Kabupaten Limapuluh Kota. Badan Lingkungan Hidup Kebersihan dan Pertamanan, 2013.

[10] Daoed, D., Sunaryo, S., Istijono, B., and Utama, W. P. Kinerja Perkuatan Tebing Saluran Dengan Bronjong di Belokan 120o Akibat Banjir Bandang (Uji Eksperimental di Laboratorium). Jurnal Rekayasa Sipil (JRS-UNAND), 2015, 11(1), 11-22. 